\title{
LIQUID SCINTILLATION COUNTING IN THE LONDON UNDERGROUND
}

\author{
SHERIDAN BOWMAN \\ British Museum Research Laboratory \\ London WC1B 3DG, England
}

\begin{abstract}
At the 12th International Radiocarbon Conference held in Trondheim, the potential of the London Underground as a site for liquid scintillation counting was considered (Bowman, 1986). This was discussed in light of a survey of three possible locations using a portable gamma-ray spectrometer. Two liquid scintillation counters, a Packard 3255 and an LKB "Kangaroo". have now been successfully installed in a vault which is some $30 \mathrm{~m}$ below ground. The reduction in background count rates achieved is discussed, together with other improvements made to the counting system.
\end{abstract}

\section{INTRODUCTION}

Massive physical shielding (ie, deep underground siting) to reduce the cosmic-ray contribution to background count rates in low-level liquid scintillation counting has been reported by various authors (Schotterer \& Oeschger, 1980; Calf \& Airey, 1982; Loosli, Forster \& Otlet, 1986; Kalin \& Long, 1989). At the 12th International Radiocarbon Conference held in Trondheim, the potential of the London Underground as a site for liquid scintillation counting was considered (Bowman, 1986). A survey of three potential sites using a portable gamma spectrometer showed substantial reductions in cosmic-ray flux relative to surface levels as expected. It also indicated uranium, thorium and potassium $\left({ }^{40} \mathrm{~K}\right)$ activities roughly comparable with the basement location already in use for liquid scintillation counting. The present paper gives the background levels measured after underground siting of two counters, an LKB (Wallac) "Kangaroo" (ie, a model 1217 Ultrabeta with additional features) and a Packard 3255. Both liquid scintillation counters are operating with reduced voltage, high gain and low-level discriminator set to exclude the majority of ${ }^{3} \mathrm{H}$ and, for glass, ${ }^{40} \mathrm{~K}$ pulses. The LKB also has a pulse height comparator (Soini, 1975) but is used on low bias.

In London, a number of deep sites exist, many of which are not part of the present "tube" system but which were built as part of a cross-London fast train system which was not completed. The Chenies Street site was chosen for its proximity to the Museum and accessibility to the underground vaults, which are some $30 \mathrm{~m}$ below street level.

Before presenting the results of underground siting of the counters, improvements made to minimize evaporation losses from the counting system are briefly discussed. These include various computer checks to look for variability and time-dependent trends in the count rates from samples and standards, and better sealing procedures for vials (as Otlet \& Slade, 1974). 


\section{EVAPORATION LOSSES}

General improvements to the system have been made and are summarized in Bowman and Ambers (in press). In particular, evaporation losses are guarded against, since results issued by the British Museum radiocarbon laboratory between 1980 and 1984 were in error because of such losses from moderns and backgrounds (Tite et al, 1987, 1988; Bowman $\&$ Ambers, in press; a full account of the problem including revised results and details of their evaluation is in preparation). To prevent evaporation losses, samples and standards could be flame-sealed into all glass vials. However, given that the vials cannot be re-used, no check can be made for differences in background and efficiency vial to vial (Ambers, Leese \& Bowman, 1986). Although such problems have not been observed in testing of batches of vials by Cook (pers commun, 1987), the approach adopted here has been to select vials for closely similar backgrounds, to re-use them, to minimize evaporation losses and to run computerized checks for such losses. The low-potassium glass vials in use for samples are sealed with a "Tufbond" seal (PTFE disc plus silicone rubber backing manufactured by Pierce \& Warriner, Chester). This is placed inside the plastic cap of the vial after removal of the commercially supplied seal, which comprises cork with a metal foil disk. In addition to the "Tufbond", an indium seal is used for the standards. The combination of the two was advocated by Otlet and Slade (1974), and was shown by Burleigh and Hewson (1975) to have substantially superior sealing properties than the cap as commercially supplied. Regrettably, the system was not implemented at the British Museum, apparently because it was believed that the indium contributed to the background.

Recent checks have been made on relative evaporation losses and on contributions to background count rate. The evaporation loss measurements were at room temperature with empty, but appropriately sealed vials, being used to monitor weight changes due to absorption (or loss) of moisture from the atmosphere. The results were in broad agreement with those of Burleigh and Hewson (1975) with the commercially supplied seal losing more than ten times as much as the indium plus "Tufbond" (maximum losses over two months at room temperature were 80 relative to $6 \mathrm{mg}$, respectively). Grinding of the mouth of the vial prior to use of the indium seal was not found to have any significant effect on weight loss.

Background samples $(15 \mathrm{ml}$ of benzene plus scintillator in a $20 \mathrm{ml}$ lowpotassium glass vial) showed no detectable increase in count rate with indium seals, contrary to the expectations of Burleigh and Hewson (1975: it should be noted that these authors do not indicate that such samples were counted, only that indium decays emitting a beta particle of $0.6 \mathrm{Mev}$, also, the half-life quoted was in error and should be $6 \times 10^{14} \mathrm{yr}$, not $6 \times 10^{4} \mathrm{yr}$ ). Similarly, Otlet (pers commun, 1985) has not observed any significant increase in background attributable to indium.

Each counter has at least two moderns and two backgrounds, the replacement of which is staggered in time. Computerized checks are run to look for high variability amongst counts for a given sample or standard, variability amongst moderns or backgrounds and time trends in counts to look 
specifically for evaporation. In addition, samples of wood, kindly supplied by Mike Baillie, which have been dated by the Belfast high-precision laboratory, are used as checks on accuracy.

The possibility of using PTFE vials (LKB Wallac, manufactured to the design of Calf \& Polach, 1974) has been considered for reducing background levels. The evaporation losses from such vials has not been systematically studied in this laboratory, but from general usage, appears comparable with that from glass vials with the commercially supplied seal of cork plus foil.

\section{BACKGROUND REDUCTION UNDERGROUND}

Results

Table 1 shows the background rates in the LKB 'above' and 'below' ground for the three types of counting vial. The 'above' ground laboratory in fact is a basement beneath one load-bearing floor and a glass roof, which together correspond roughly to $800 \mathrm{~kg} \mathrm{~m}^{-2}$ of overburden. The underground site is nominally $36 \mathrm{~m}$ deep, but from the results of the gamma spectrometer survey of this and two other sites (Bowman, 1986) it is likely that the overburden is nearer to $30 \mathrm{~m}$ of London clay (hence, roughly $7 \times 10^{4} \mathrm{~kg} \mathrm{~m}^{-2}$ ). There are more limited data (see Table 2) for the Packard 3255 than for the LKB, since the contributions to background in this counter were not studied prior to its removal to the underground site (note that this is not the same counter discussed in Bowman, 1986). Furthermore, the one direct comparison which could have been made above and below ground was obscured by the ${ }^{226} \mathrm{Ra}$ source becoming stuck in the flight tube.

\section{DISCUSSION}

For the $\mathrm{LKB}$, an $18 \%$ reduction in background count rate has been achieved for $20 \mathrm{ml}$ glass vials with $15 \mathrm{ml}$ of benzene plus scintillator solution by underground siting. Given that the background due to gamma rays may not be the same in the new location as in the original site in the laboratory, the observed reduction compares reasonably well with the anticipated $25 \%$ (Bowman, 1986). Note that the tables also include data on the effect of removal of the ${ }^{226} \mathrm{Ra}$ source. Quench checks are now done using sample channels ratio. Not only was there a contribution to background levels of ca $10 \%$, but the sensitivity to quench was poor using this external standard source due to the relatively high energy of the gamma emission and the consequent secondary electron spectrum. 
TABLE 1

Background count rates* for glass and PTFE vials in LKB "Kangaroo"

\begin{tabular}{|c|c|c|c|}
\hline & $\begin{array}{l}\text { Basement lab } \\
\text { (cpm) }\end{array}$ & $\begin{array}{l}\text { Underground } \\
(\mathrm{cpm})\end{array}$ & Efficiency** \\
\hline Empty glass vial (20ml) & 1.05 & 0.10 & \\
\hline Glass vial $(20 \mathrm{ml})+$ background $^{\dagger}(15 \mathrm{ml})$ & 3.90 & $\begin{array}{l}3.17 \\
2.81^{\neq}\end{array}$ & $69 \%$ \\
\hline Glass vial $^{\S}$ ("20ml”) + background $(5.5 \mathrm{ml})$ & - & $\begin{array}{l}1.21 \\
1.08^{+}\end{array}$ & $63 \%$ \\
\hline Empty PTFE vial (15ml) & 1.54 & $0.20^{+}$ & \\
\hline PTFE vial $(15 \mathrm{ml})+$ background $(15 \mathrm{ml})$ & 3.20 & $2.29^{*}$ & $65 \%$ \\
\hline Empty PTFE vial ${ }^{*}(7 \mathrm{ml})$ & - & 0.10 & \\
\hline PTFE vial $(7 \mathrm{ml})+$ background $(5.5 \mathrm{ml})$ & 1.38 & $\begin{array}{l}1.07 \\
0.90^{*}\end{array}$ & $66 \%$ \\
\hline Empty glass vial $^{\S}(6 \mathrm{ml}+$ plastic carrier $)$ & - & $0.25^{+}$ & \\
\hline Empty plastic carrier & - & $0.20^{*}$ & \\
\hline Glass vial $(6 \mathrm{ml})+$ background $(5.5 \mathrm{ml})$ & - & $1.50^{\mp}$ & $71 \%$ \\
\hline
\end{tabular}

* Errors on each count rate are typically 5-10\%. The windows set for low-potassium glass and coppercapped PTFE vials are the same width, but the latter starts at lower pulse height than the former.

** Note in any comparison between data here and in Bowman (1986) that the efficiencies given in the latter were in error.

$\dagger$ The $15 \mathrm{ml}$ background samples comprised $5.5 \mathrm{ml}$ of benzene synthesized from anthracite plus $9.5 \mathrm{ml}$ of PPO in toluene at a concentration of $4 \mathrm{~g}^{-1}$. The $5.5 \mathrm{ml}$ background samples comprised $5.5 \mathrm{ml}$ of benzene plus butyl-PDB to give a concentration of $16 \mathrm{~g} 1^{-1}$.

\# The count rates so marked are with the ${ }^{226} \mathrm{Ra}$ source removed.

$\S$ The glass vials are Packard low-potassium; there can be batch variations in background; hence, the data here are not the same as in Bowman (1986). The $6 \mathrm{ml}$ vial has a plastic carrier. The top of the $20 \mathrm{ml}$ glass vial with $5.5 \mathrm{ml}$ background was covered with black tape. Note, however, that the sample was not in the center of the counting area.

\# The copper-capped PTFE vials were supplied by Wallac to a design similar to that of the aluminiumcapped vials of Calf and Polach (1974).

\section{TABLE 2}

Count rates for glass and PTFE vials in Packard*

\begin{tabular}{|c|c|c|c|}
\hline & $\begin{array}{l}\text { Basement lab } \\
(\mathrm{cpm})\end{array}$ & $\begin{array}{l}\text { Underground } \\
(\mathrm{cpm})\end{array}$ & Efficiency \\
\hline Empty glass vial (20ml) & - & $0.76^{* *}$ & \\
\hline Glass vial $(20 \mathrm{ml})+$ background $(15 \mathrm{ml}) \dagger$ & 9.05 & $\begin{array}{l}\sim 5.0 \\
4.30^{* *}\end{array}$ & $71 \%$ \\
\hline Empty PTFE vial (7ml) & - & $0.35^{* *}$ & \\
\hline PTFE vial $(7 \mathrm{ml})+$ background $(5.5 \mathrm{ml})$ & - & $1.58^{* *}$ & $68 \%$ \\
\hline Empty glass vial $(6 \mathrm{ml}+$ plastic carrier $)$ & - & $1.22^{* *}$ & \\
\hline Glass vial $(6 \mathrm{ml})+$ background $(5.5 \mathrm{ml})$ & - & $2.70^{* *}$ & $71 \%$ \\
\hline
\end{tabular}

* Note that this is not the counter discussed in Bowman (1986).

** Count rates so marked are with the ${ }^{226} \mathrm{Ra}$ source removed. The count rate for a background in a $20 \mathrm{ml}$ glass vial prior to removal of this source is approximate because the source was stuck in the flight tube.

$\dagger$ See notes to Table 1 for scintillator used and origin of vials. 
In the Packard, for the same counting system, the overall reduction in background count rate has been $>50 \%$, ie, for underground siting plus ${ }^{226} \mathrm{Ra}$ removal.

With regard to vial size and type, the sample size currently used typically gives ca $5.5 \mathrm{ml}$ of benzene. It is clearly advantageous to employ a benzene only counting system and use a volume that, while standardized, is as near to that produced by a typical sample. The former means that evaporation losses are more directly relatable to weight losses and the latter helps to minimize background count rates for a given sample size. The cocktail of PPO in toluene previously used (see notes to Table 1) satisfied neither criteria. Use of butyl-PBD will provide a benzene only cocktail. In reducing the volume, however, there is the difficulty of what vial to use. For $15 \mathrm{ml}$, the difference in background between low potassium glass $(20 \mathrm{ml}$ size) and PTFE $(15 \mathrm{ml})$ is not great (Bowman, 1986 and Table 1) and the figures of merit reasonably comparable, so the disadvantages of using the latter were not outweighed. These include cost, memory effects, tendency to distort and difficulties with adequate sealing; also, Pearson (pers commun, 1987) has found large variations in pulse height from vial to vial. For a reduction in volume to $5.5 \mathrm{ml}$, use of a $20 \mathrm{ml}$ glass vial gives a background count rate in the LKB which is ca $20 \%$ greater than for a $7 \mathrm{ml}$ PTFE vial; however, there is a loss of efficiency since the sample is not central in the counting chamber. The consequent figure of merit is therefore $25 \%$ lower than for the small PTFE vial. While the reduced figure of merit may be acceptable, the use of a small sample in a $20 \mathrm{ml}$ vial may have another disadvantage. Any inhomogeneity vial to vial is likely to be accentuated at the base where the glass is thickest. Background and efficiency variations are therefore possible. The $6 \mathrm{ml}$ glass vial gives increased efficiency relative to $5.5 \mathrm{ml}$ in a $20 \mathrm{ml}$ glass, but the background also increases and the figure of merit is therefore worse. The increase in background appears to have some contribution from the plastic carrier, but is presumably mainly due to the increased surface area of sample in contact with the glass.

\section{SUMMARY}

Substantial reductions in background have been achieved by siting two liquid scintillation counters underground and by use of a smaller counting volume. The underground siting was particularly advantageous for the older of the two counters (the Packard 3255) which, unlike the LKB, does not have a pulse height comparator.

The smaller counting volume has raised the question of which is the best counting vial to use. While this question is far from new, the literature tends to extol the virtues of the system with the lowest background and highest figure of merit. The disadvantages of the consequent system are rarely expressed. On this basis, the data presented here would promote, as elsewhere, the use of PTFE. In practice, however, having substantially lower evaporation losses for glass vials and the possibility of vial selection are significant plus factors. The choice remains a problematic one. 


\section{ACKNOWLEDGMENTS}

I wish to thank, in particular, Janet Ambers for performing the evaporation experiments and for help in the preparation of this paper. I thank Morven Leese for implementing the computer checks and Michael Tite for reading and commenting on the manuscript.

\section{REFERENCES}

Ambers, J, Leese, M and Bowman, S, 1986, Detection of bias in the background of vials used for scintillation counting, in Stuiver, $\mathrm{M}$ and $\mathrm{Kra}, \mathrm{R} \mathrm{S}$, eds, Internatl ${ }^{14} \mathrm{C}$ conf, 12th, Proc: Radiocarbon, v 28, no. 2A, p 586-591.

Bowman, S, 1986, The potential of the London Underground for liquid scintillation counting, in Stuiver, $\mathrm{M}$ and Kra, R S, eds, Internatl ${ }^{14} \mathrm{C}$ conf, 12th, Proc: Radiocarbon, v 28, no.2A, p 592-596.

Bowman, S G E and Ambers, J C, in press, Past and present: the identification of an error in, and the present status of, radiocarbon dating at the British Museum, in Waterbolk, H T, ed, Internatl symposium, Archaeology and ${ }^{14} \mathrm{C}, 2$ nd, Proc: PACT, Strasbourg.

Burleigh, R and Hewson, A, 1975, Evaporation losses of organic samples from liquid scintillation counting vials, in Crook, M A and Johnson, P, eds, Liquid scintillation counting: London, Heyden, p 207-213.

Calf, G E and Airey, P L, 1982, Liquid scintillation counting of C-14 in a heavily shielded site, in Ambrose, W and Duerden, $\mathrm{P}$, eds, Archaeometry: an Australian perspective: Canberra, Australian Natl Univ Press, p 351-356.

Calf, G E and Polach, H A, 1974, Teflon vials for liquid scintillation counting of carbon-14 samples, in Stanley, P E and Scoggins, B A, eds, Liquid scintillation counting - recent developments: New York, Academic Press, p 223-234.

Loosli, H H, Forster, M and Otlet, R L, 1986, Background measurements with different shielding and anticoincidence systems in Stuiver, $\mathrm{M}$ and $\mathrm{Kra}, \mathrm{R} \mathrm{S}$, eds, Internatl ${ }^{14} \mathrm{C}$ conf, 12th, Proc: Radiocarbon, v 28, no.2A, p 615-624.

Kalin, R and Long, A, 1989, Radiocarbon dating with the Quantulus in an underground laboratory: Performance and background sources: Radiocarbon, this issue.

Otlet, R L and Slade, B S, 1974, Harwell radiocarbon measurements I: Radiocarbon, v 16, no.2, p 178-191.

Schotterer, U and Oeschger, H, 1980, Low-level liquid scintillation counting in an underground laboratory, in Stuiver, $\mathrm{M}$ and $\mathrm{Kra}, \mathrm{R} \mathrm{S}$, eds, Internatl ${ }^{14} \mathrm{C}$ conf, 10 th, Proc: Radiocarbon, $v$ 22, no.2, p 505-511.

Soini, E, 1975, Rejection of optical cross-talk in photomultiplier tubes in liquid scintillation counters: Research rept, Wallac Oy, Turku, Finland.

Tite, M S, Bowman, S G E, Ambers, J C and Matthews, K J, 1987, Preliminary statement on an error in British Museum radiocarbon dates (BM-1700 to BM-2315): Antiquity, v61, no. $232, \mathrm{p} 168$.

- 1988, Preliminary statement on an error in British Museum radiocarbon dates (BM-1700 to BM-2315): Radiocarbon, v 30, no. 1, p 132. 